
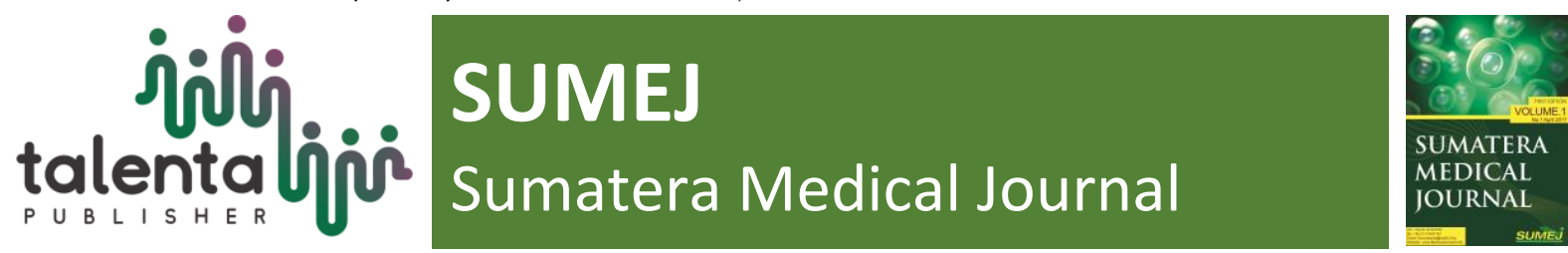

\title{
Quality of Life in Vitiligo Patients at H. Adam Malik General Hospital Medan, Indonesia
}

\author{
Nelva Karmila Jusuf ${ }^{1^{*}}$, Imam Budi Puta², Dina Rizki Utami ${ }^{3}$ \\ ${ }^{1,2}$ Departement of Dermatology and Venereology Faculty of Medicine, Universitas Sumatera Utara \\ ${ }^{3}$ Postgraduate of Dermatology and Venereology, Faculty of Medicine, Universitas Sumatera Utara
}

\begin{abstract}
Vitiligo is an acquired depigmenting skin disorder that can affect the patients' quality of life (QOL). The aim of this study was to evaluate the QOL in patients with vitiligo. The methods of his study included 30 patients with vitiligo. All the patients filled out questionnaires Skindex-29. Data were compiled and analyzed statistically. The results: showed among the 30 vitiligo patients, $73,3 \%$ were women and $26,7 \%$ were men. Mean age of patients were $40.53 \pm 12$. 91 years old. The mean duration of vitiligo was $9.07 \pm 7.643$ years. The mean total Skindex-29 score of the subjects was $24.68 \pm 7,72$. There was significant difference according to age's group $(p=0,035)$ and $\operatorname{sex}(p=0,01)$ but there is no significant difference according to duration of disease's group $(p=0,582)$. The Conclusion of this research showed that vitiligo has a significant effect on the patients' QOL. It seems counselling is needed as part of treatment in vitiligo patients.
\end{abstract}

Keyword: Vertiligo, Quality of Life, Skindex-29

\begin{abstract}
Abstrak. Vitiligo adalah gangguan kulit depligasi yang dapat mempengaruhi kualitas hidup pasien (QOL). Tujuan dari penelitian ini adalah untuk mengevaluasi kualitas hidup pada pasien dengan vitiligo. Metode penelitian ini termasuk 30 pasien dengan vitiligo. Sетиa pasien mengisi kuesioner Skindex-29. Data dikumpulkan dan dianalisis secara statistik. Hasil dari penelitian ini menunjukkan di antara 30 pasien vitiligo, 73,3\% adalah wanita dan 26,7\% adalah laki-laki. Usia rata-rata pasien adalah 40,53 \pm 12 . 91 tahun. Durasi rata-rata vitiligo adalah 9,07 $\pm 7,643$ tahun. Jumlah total skor Skindex-29 subjek adalah 24,68 $\pm 7,72$. Ada perbedaan yang signifikan menurut kelompok usia $(p=0,035)$ dan jenis kelamin $(p=0,01)$ tetapi tidak ada perbedaan yang signifikan menurut durasi kelompok penyakit $(p=0,582)$. Kesimpulan dari penelitian ini menunjukkan bahwa vitiligo memiliki efek yang signifikan pada kualitas hidup pasien. Tampaknya konseling diperlukan sebagai bagian dari perawatan pada pasien vitiligo.
\end{abstract}

Kata Kunci: Vertiligo, Kualitas Hidup, Skindex-29

Received 30 May 2018 | Revised 10 July 2018 | Accepted 25 September 2018

\section{Introduction}

A healthy normal skin is essential for a person's physical and mental well being. It is an important aspect of their sexual attractiveness, a sense of well being and a sense of self confidence [1].

\footnotetext{
*Corresponding author at: Faculty of Medicine, Jalan Doktor Mansyur No.5 Kampus USU Padang Bulan, Medan, Sumatera Utara 20155
} 
Vitiligo is a common condition seen in a dermatology office, which has a variety of comorbidities. Worldwide, the prevalence of vitiligo ranges from 0.4 to $2.0 \%$, with regions of greater or lesser prevalence [2]. Jusuf and Meher based on medical records found in 2012 total vitiligo patients were 18,09\% of total visits in Cosmetic Division of Outpatient Dermatology and Venereology Clinic in H. Adam Malik General Hospital Medan, in 2013 were 9,21\%, 2014 were 8,53\% and 2015 were 8,45\% [3]. Most studies demonstrate slightly greater prevalence in females [2]. Vitiligo is a common depigmenting skin disorder, characterized by acquired, idiopathic, progressive, circumscribed hypomelanosis of the skin and hair, with total absence of melanocytes microscopically [4]. Vitiligo is an important skin disease having major impact on quality of life of patients, many of whom feel distressed and stigmatized by their condition [1]. The psychosocial aspects of vitiligo can be described by stress as a potential cause or effect of the disease, the anxiety or depression of vitiligo patients, or the impact of vitiligo on patient quality of life [5]. In a research conducted by Hamdani and Jusuf found pigmentation disorder on face were greatly affecting $(54,0 \%)$ quality of life in subjects at 21 Posyandu in Medan Labuhan [6].

\section{Methodology}

This Patient with confirmed diagnosis of vitiligo were included in this study. Our sampling method was consecutive sampling. Inclusion criteria were diagnosis of vitiligo by a dermatologist and 18 years or above. Exclusion criteria included diagnosis of skin diseases other than vitiligo, other chronic disease or any conditions that might have an effect on QOL, and apparent disability. The study was conducted in the Dermatology Outpatient Clinic of H. Adam Malik General Hospital Medan, Indonesia from June 2016 to September 2016. Those who were referred to the clinic and met the eligibility criteria were recruited. Each subject was explained about the study and asked to answer the questions in Skindex-29. This tool inquired about how often (never, rarely, sometimes, often, all the time) during the previous 4 weeks the patient experienced the effect described in each item. Seven items address the symptoms domain, 10 items the emotional domain, and 12 items the functioning domain. All responses are transformed to a linear scale of 100, varying from 0 (no effect) to 100 (effect experienced all the time). Skindex scores are reported as three scale scores, corresponding to the three domains; a scale score is the average of a patient's responses to items in a given domain [7]. All data from subjects then were analyzed statistically.

\section{Results}

Among the 30 vitiligo patients, 8 patients were men and 22 were women. Most patients were 4049 years old $(40 \%)$ with mean age was $40.53 \pm 12.91$ years old. $40 \%$ of participants had vitiligo for 1-5 years with mean duration of vitiligo was $9.07 \pm 7.643$ years. Most subjects were working as private employee and finishing high school (Table 1). Based on categorization of total scores, 
most patients were in moderately affected category (70\%) (Table 2). The mean total skindex-29 score of the subjects was $24.68 \pm 7,72$ (Table 3). There is significant difference according to age $(\mathrm{p}=0,035)$ and $\operatorname{sex}(\mathrm{p}=0,01)$ but there is no significant difference according to duration of disease $(\mathrm{p}=0,582)$. According to age category, the highest mean total score was found in $<20$ years old group $(35,00 \pm 0,00)$ and based on gender, female attained higher mean score $(27,13 \pm 7,55)$ than male $(17,95 \pm 2,31)$ (Table 4$)$.

Table 1. Distribution of Subjects Based on Demographic and Clinical Characteristics

\begin{tabular}{|c|c|c|}
\hline Variable & $n$ & $\%$ \\
\hline \multicolumn{3}{|l|}{ Age (years old) } \\
\hline$<20$ & 1 & 3,3 \\
\hline 20- 29 & 6 & 20 \\
\hline 30- 39 & 18 & 36 \\
\hline 50- 59 years & 16 & 32 \\
\hline 60- 69 years & 4 & 8 \\
\hline 70- 79 years & 1 & 2 \\
\hline \multicolumn{3}{|l|}{ Sex } \\
\hline Female & 22 & 73,3 \\
\hline Male & 8 & 26,7 \\
\hline \multicolumn{3}{|l|}{ Education } \\
\hline Elementary & 3 & 10 \\
\hline Junior high school & 2 & 6,7 \\
\hline Senior high school & 14 & 46,7 \\
\hline University & 11 & 36,7 \\
\hline \multicolumn{3}{|l|}{ Occupation } \\
\hline Civil Officer & 4 & 13,3 \\
\hline Enterprenuer & 7 & 23,3 \\
\hline Private employee & 11 & 36,7 \\
\hline Unemployment & 12 & 24 \\
\hline \multicolumn{3}{|c|}{ Duration of disease (years) } \\
\hline $1-5$ & 12 & 40 \\
\hline $6-10$ & 6 & 20 \\
\hline $11-15$ & 7 & 23,3 \\
\hline $16-20$ & 4 & 13,3 \\
\hline$>20$ & 1 & 3,3 \\
\hline
\end{tabular}




\begin{tabular}{|c|c|c|c|c|}
\hline \multirow{5}{*}{$\begin{array}{c}\text { Table } 2 . \\
\text { Subject Based on } \\
29 \text { Score }\end{array}$} & Total Score & Category & $\mathbf{n}$ & $\%$ \\
\hline & $<5$ & Very little & 0 & 0 \\
\hline & $6-17$ & Mild & 9 & 30 \\
\hline & $18-36$ & Moderate & 21 & 70 \\
\hline & $\geq 37$ & Severe & 0 & 0 \\
\hline
\end{tabular}

Distribution quality of life scores in this study showed 38 (76\%) subjects had a very high quality of life and $12(24 \%)$ subjects had a high quality of life and we didn't find a moderate or low quality of life score in all subjects (Table 2), furthermore based on the characteristics of the skin tag lesions we also didn't find a significant difference in the quality of life score from all subject (Table 4).

Table 3. Total Score of Skindex-29

\begin{tabular}{lccccc}
\hline & n & Minimum & Maximum & Mean & $\begin{array}{c}\text { Std. } \\
\text { Deviation }\end{array}$ \\
& & & & & \\
\hline Total & 30 & 16.70 & 35.00 & 24.68 & 7.7224 \\
Score & & & & 00 & \\
\hline
\end{tabular}

Table 4. Distribution Category of Quality of Life

\begin{tabular}{|c|c|c|}
\hline Variable & Mean of total score \pm SD & $\mathbf{P}$ \\
\hline \multicolumn{3}{|l|}{ Sex } \\
\hline Male & $17,95 \pm 2,31$ & 0,001 \\
\hline Female & $27,13 \pm 7,55$ & \\
\hline \multicolumn{3}{|c|}{ Age (years old) } \\
\hline$<20$ & $35,00 \pm 0,00$ & \\
\hline $20-29$ & $31,95 \pm 7,47$ & \\
\hline $30-39$ & $21,70 \pm 0,00$ & \\
\hline $40-49$ & $20,84 \pm 5,18$ & 0,035 \\
\hline $50-59$ & $16,70 \pm 9,15$ & \\
\hline$\geq 60$ & $24,68 \pm 0,00$ & \\
\hline \multicolumn{3}{|c|}{ Duration of } \\
\hline \multicolumn{3}{|c|}{ Disease (years) } \\
\hline $1-5$ & $23,64 \pm 7,69$ & \\
\hline $6-10$ & $23,08 \pm 6,17$ & \\
\hline $11-15$ & $25,97 \pm 8,69$ & 0,582 \\
\hline
\end{tabular}




\begin{tabular}{ll}
$16-20$ & $28,68 \pm 8,83$ \\
$\geq 20$ & $16,70 \pm 0,00$ \\
\hline
\end{tabular}

\section{Discussion}

Vitiligo considerably influences the psychological well-being of patients. Disease-induced disfigurement can cause patients to experience a high level of stigmatization, which can lead to psychosocial stresses and negative impacts on quality of life (QOL) [8]. Vitiligo is a multifactorial pigmentary skin disorder. Recently, the importance of emotional and psychological issues is proposed in incidence, progression, relapse and remission of vitiligo. There are limited studies conducted in developing countries, which assess life quality of patients with vitiligo [9].

Kim et al in Korea conducted a study regarding the impact of vitiligo in patient' life with similar tool. This study was involving one hundred and thirty-three vitiligo patients and 112 patients with mild skin disorders. They found the symptom scale of Skindex-29 was significantly lower in vitiligo patients than in controls, but the function scale and the emotion scale were significantly higher in the vitiligo group than in controls. However, the difference in function scales between groups was significant in female patients, but not in male patients. Several clinical profiles, such as duration of disease, severity scores and previous history of treatments, showed close correlations with the function scale. Family history of vitiligo, Köebner phenomenon, patients' perspectives on disease prognosis, and discordance of the severity scores between physicians and patients also influenced the Skindex-29 subscales differently. In their conclusion, the study suggests that patients with vitiligo were highly affected in the functional and emotional aspects of QOL, with some sex differences and perhaps various clinical features may play an important role in the QOL of vitiligo patients [8]

Study by Ghaderi and Saadatjo in Iran involved 70 patients with vitiligo. All the patients filled out two questionnaires: Short Form 36 (SF-36) and Dermatology Life Quality Index (DLQI). The mean score of patients with vitiligo on DLQI scale was $8.40 \pm 5.76$ (range, 0-23). Although males scores on SF-36 scale was higher than females, the difference was not statistically significant. With regard to age, the mean total score of SF-36 indicated insignificant differences among age groups. Their findings showed that vitiligo has a significant effect on the patients' QOL [10].

Hedayat et al conducted a study on 25 patients as a pilot and another 173 patients as the main study group, in Razi Hospital, Tehran, Iran, 2013-2014. Persian version of Vitiligo Quality of Life index (VitiQoL) was developed with backward-forward method. The Vitiligo Area and Score Index (VASI), VitiQoL, and their relationship, demographic and clinical characteristic of patients were measured. The Mean and standard deviation of the VitiQoL score was $30.5 \pm 14.5$ (range 0-60 in Persian version). They found a significant relationship between VASI score and VitiQoL $(\mathrm{p}=0.015, \mathrm{r}=0.187$. Based on behavior factor, female patients had poorer quality of life $(\mathrm{p}=$ 0.02). Concomitant psychiatric problems, e.g. anxiety and depression, were not associated with QOL; however, they were near to being meaning $(\mathrm{p}=0.06, \mathrm{r}=0.14)$ [9]. 
A study by Karia et al tried to determine the psychiatric morbidity and the QOL in patients suffering from vitiligo and to determine the factors related with psychiatric morbidity and those affecting the QOL in vitiligo patients. 50 patients of age range $18-65$ years with disease duration of 1-26 years attending the vitiligo clinic in dermatology outpatient department of a tertiary care hospital were included and 50 persons with no dermatological or diagnosed psychiatric illness accompanying them served as control group. They found 30\% patients in vitiligo group suffered from psychiatric disorder, depression was present in $20 \%$ of patients and $8 \%$ had anxiety disorder. That it was found that vitiligo patients had more psychiatric comorbidities as compared to control group and it had bearing on their quality of life too [11].

Vitiligo is an acquired depigmentary skin disorder characterized by white macules on the skin associated with social stigma. Vitiligo has major impact on the quality of life due its high cosmetic value, chronic nature of disease and long term ineffective treatments. Vitiligo patients suffer from low self-esteem and poor body image that affects their emotional and psychological well-being. To investigate quality of life of $v$ itiligo patients, psychological impact of unpredictable course of disease and long term treatment among South Indian population Mateen et al conducted a study involving a total of 155 vitiligo patients who were undertaking treatment in dermatology clinic at the Central Research Institute of Unani Medicine. They found patients with vitiligo averaged at about $27.4 \%$ of maximum psychological impairment as measured by the Dermatology Quality of Life Index (DQLI) summary score. Disability in patients was highest in treatment category with $54.6 \%$ of impairment followed by symptoms and feelings (41.83\%). Dark skin, unmarried, slow responders to the treatment and those having chronicity more than 5 years showed worse quality of life and had $70 \%, 61 \%, 62 \%$ and $76.5 \%$ of impairment in the treatment front of DLQI respectively when compared to light skin (50\%), married (52.5\%), rapid responders (26\%) and chronicity less than 5 years $(52 \%)$. There was no significant difference in the quality of life between male and female Vitiligo patients. Their results show that vitiligo patients suffer in all aspects of life especially in treatment aspect of DLQI and psychological impairment strongly affects the social well-being of vitiligo patients [12].

A study group comprised of 54 subjects with vitiligo, 57 with psoriasis and 57 unaffected controls with all subjects were examined and interviewed using the DLQI and Emotional State questionnaires. They found total mean DLQI score in vitiligo was 4.7, compared with 0.6 in healthy controls ( $\mathrm{p}<0.001)$ and 13.1 in psoriasis $(\mathrm{p}<0.001)$. In vitiligo, females experienced a greater impact on feelings and men experienced a greater impact on relationships. Lower quality of life in vitiligo was associated with active stage of the disease, extension of pigment loss, depigmentation on the hands, and earlier onset of disease. The results demonstrate that vitiligo has less impact on quality of life than psoriasis. This case-control study of fair-skinned subjects demonstrates the low level of disease-related impairment in QOL in vitiligo compared with the severe impairment in QOL in psoriasis [13] 
In our study, we found the mean total skindex-29 score of the subjects was $24.68 \pm 7,72$.

According to Nijsten categorization, it fell on moderate category [14]. There is significant difference according to age's group $(p=0,035)$ and $\operatorname{sex}(p=0,01)$ but there is no significant difference according to duration of disease $(\mathrm{p}=0,582)$. This might be because women and younger people are more concern in appearance than men and older ones.

\section{Conclusion}

Vitiligo can affect patient's quality of life because cosmetically disturbing. Counselling may be needed as part of treatment to improve subjects and their families' attitude toward this disease.

\section{REFERENCES}

[1] D. Parsad, S. Dogra, and A. J. Kanwar, "Quality of life in patients with vitiligo," Health and quality of life outcomes, vol. 1, no. 1, p. 58, 2003.

[2] N. B. Silverberg, "The epidemiology of vitiligo," Current Dermatology Reports, vol. 4, no. 1, pp. 36-43, 2015.

[3] N. Jusuf and C. Meher, "Pola Kelainan Pigmentasi di Poliklinik Kulit dan Kelamin Divisi Kosmetik RSUP H. Adam Malik Medan Tahun 2012-2015," Pertemuan Ilmiah Tahunan XV Ilmu Kesehatan Kulit dan Kelamin. Padang. Indonesia.

[4] R. Yaghoobi, M. Omidian, and N. Bagherani, "Vitiligo: a review of the published work," The Journal of dermatology, vol. 38, no. 5, pp. 419-431, 2011.

[5] L. Manolache, "The psychosocial aspects of vitiligo: A focus on stress involvement in children with vitiligo," in Vitiligo-Management and Therapy, InTech, 2011.

[6] S. M. Hamdani, "Gambaran Kualitas Hidup Penderita Kelainan Pigmentasi Wajah pada Pengunjung Posyandu di Kecamatan Medan Labuhan," Gambaran Kualitas Hidup Penderita Kelainan Pigmentasi Wajah pada Pengunjung Posyandu di Kecamatan Medan Labuhan, 2015.

[7] M.-M. Chren, "The Skindex instruments to measure the effects of skin disease on quality of life," Dermatologic clinics, vol. 30, no. 2, pp. 231-236, 2012.

[8] D. Y. Kim, J. W. Lee, S. H. Whang, Y. K. Park, S.-K. HANN, and Y. J. Shin, "Quality of life for Korean patients with vitiligo: Skindex-29 and its correlation with clinical profiles," The Journal of dermatology, vol. 36, no. 6, pp. 317-322, 2009.

[9] K. Hedayat et al., "Quality of life in patients with vitiligo: a cross-sectional study based on Vitiligo Quality of Life index (VitiQoL)," Health and quality of life outcomes, vol. 14, no. 1, p. 86, 2016.

[10]R. Ghaderi and A. Saadatjoo, "Evaluating of Life Quality in Iranian Patients With Vitiligo Using Generic and Special Questionnaires," Shiraz E-Medical Journal, vol. 15, no. 3, 2014.

[11]S. Karia, A. D. Sousa, N. Shah, S. Sonavane, and A. Bharati, "Psychological Morbidity in Vitiligo-A Case Control Study," Pigmentary Disorders, vol. 2, no. 170, pp. 2376-0427, 2015.

[12]A. Mateen, R. Syed, K. K. Alharbi, and I. A. Khan, "An Overview of Quality of Life in Vitiligo Patients-At Glance," Pigmentary Disorders S, vol. 3, pp. 2376-0427, 2015.

[13]M. Karelson, H. Silm, and K. Kingo, "Quality of life and emotional state in vitiligo in an Estonian sample: comparison with psoriasis and healthy controls," Acta dermatovenereologica, vol. 93, no. 4, pp. 446-450, 2013.

[14]T. Nijsten, F. Sampogna, and D. Abeni, "Categorization of Skindex-29 scores using mixture analysis," Dermatology, vol. 218, no. 2, pp. 151-154, 2009. 